\title{
Researching Interventions to Improve Medication Adherence in Ulcerative Colitis Patients
}

\section{Pesquisando intervenções para a melhoria da adesão à medicação em pacientes com colite ulcerativa}

\author{
Mila Palma Pacheco ${ }^{1(1)}$ Flora Maria Lorenzo Fortes ${ }^{10}$ Raquel Rocha dos Santos ${ }^{2(1)}$ \\ Genoile Oliveira Santana Silva1울
}

1 Departament of Life Sciences, Programa de Pós-graduação em Ciências Farmacêuticas (PPGFARMA), Universidade do Estado da Bahia (UNEB), Salvador, Bahia, Brazil

2 Escola de Nutrição, Universidade Federal da Bahia (UFBA), Salvador, Bahia, Brazil

\begin{abstract}
Address for correspondence Mila Palma Pacheco, Master, Departamento de Ciências da Vida (DCV), Programa de Pósgraduação em Ciências Farmacêuticas (PPGFARMA), Universidade do Estado da Bahia (UNEB), Rua Silveira Martins, 2.555, Cabula, 41.150000, Salvador, BA, Brazil (e-mail: mpacheco@uneb.br).
\end{abstract}

J Coloproctol 2021;41(1):96-103.

Abstract
Keywords
- medication
adherence
- colitis
- ulcerative
- inflammatory bowel

diseases
- self-management
- drug therapy

The purpose of this review was to identify interventions that improve adherence to medications in patients with ulcerative colitis (UC). The literature search was carried out between April and June 2020 in the PubMed/MEDLINE database, with the combination of MeSH terms medication adherence; intervention; ulcerative colitis; and inflammatory bowel disease. We restricted our search to articles published in English and Portuguese between March 2010 and March 2020. After the selection, recovery of fulltext articles and analysis of the defined criteria, the interventions described in the studies were classified into four domains: educational; behavioral, cognitive behavioral, and multicomponent. In total, six clinical trials met the inclusion criteria and were analyzed. Half of the studies (3; 50\%) used multicomponent interventions, 2 (33.3\%) focused on behavioral interventions, and 1 (16.7\%) applied isolated educational interventions. All studies used indirect methods to measure adherence, with an emphasis on scales and questionnaires. Half of the studies (3; $50 \%$ ) showed a positive impact on adherence in patients with UC, with evidence that multicomponent interventions, when properly implemented in a clinical trial combining direct and indirect methods to measure medication adherence, appear to increase the chances of better results. We believe that future studies focusing on improving adherence in patients with UC are necessary. received

July 19,2020

accepted

August 11, 2020
DOI https://doi.org/

10.1055/s-0041-1724053. ISSN 2237-9363. (c) 2021. Sociedade Brasileira de Coloproctologia. All rights reserved.

This is an open access article published by Thieme under the terms of the Creative Commons Attribution-NonDerivative-NonCommercial-License, permitting copying and reproduction so long as the original work is given appropriate credit. Contents may not be used for commercial purposes, or adapted, remixed, transformed or built upon. (https://creativecommons.org/ licenses/by-nc-nd/4.0/)

Thieme Revinter Publicações Ltda., Rua do Matoso 170, Rio de Janeiro, RJ, CEP 20270-135, Brazil 


\section{Resumo}

\author{
Palavras-chave \\ - adesão à medicação \\ - colita ulcerativa \\ - doenças inflamatórias \\ intestinais \\ - automanejo \\ - tratamento \\ farmacológico
}

O objetivo desta revisão foi identificar intervenções para a melhoria da adesão a medicamentos em pacientes com colite ulcerativa (CU). A busca na literatura foi realizada entre abril e junho de 2020 na base de dados do PubMed/MEDLINE, com a combinação dos descritores medication adherence; intervention; ulcerative colitis; e inflammatory bowel disease. Restringimos a busca aos artigos publicados em inglês e português entre março de 2010 e março de 2020. Após a seleção, recuperação dos textos dos artigos, e análise dos critérios definidos, as intervenções descritas nos estudos foram classificadas em quatro domínios: educacional; comportamental, cognitivo comportamental, e multicomponente. No total, seis ensaios clínicos atenderam aos critérios de inclusão e foram analisados. Metade dos estudos (3; 50\%) usaram intervenções do tipo multicomponente, 2 (33.3\%) centraram-se em intervenções comportamentais, e 1 (16.7\%) aplicou intervenções educacionais isoladamente. Todos os estudos utilizaram métodos indiretos para mensurar a adesão, com ênfase em escalas e questionários. Metade dos estudos (3; 50\%) demonstraram impacto positivo na adesão em pacientes com CU, com indícios de que intervenções do tipo multicomponente, quando apropriadamente implementadas em ensaio clínicos que associam métodos diretos e indiretos para a mensuração da adesão a medicamentos, parecem aumentar as chances de melhores resultados. Consideramos que estudos futuros centrados na melhoria da adesão em pacientes com CU se fazem necessários.

\section{Introduction}

Adherence is understood as the extent to which a person's behavior, such as, taking medication, following a diet and/or making lifestyle changes, corresponds to the recommendations agreed with a a healthcare provider. ${ }^{1,2}$ Some authors suggest that low adherence to drug treatment is a public health problem, with a magnitude ranging from $15 \%$ to $93 \%$ for patients with chronic diseases, and an estimated average of $50 \%$, depending on the method used; this has been characterized as an "invisible epidemic". ${ }^{3}$ The lack of adherence generates direct and indirect costs, in addition to clinical, social and environmental repercussions. Therefore, it is important not only to identify the magnitude, but also to plan and implement solutions to effectively address this issue. $^{4}$

Ulcerative colitis (UC) is a chronic disease characterized by recurrent episodes of inflammation that predominantly affect the mucous layer of the colon. Although there are no known causes, there seems to be a relationship with genetic, environmental, and immunological factors. ${ }^{5}$ The most common clinical manifestations of UC are diarrhea, rectal bleeding, mucus in the stool, abdominal pain and tenesmus. The disease is characterized by exacerbation, in which signs and symptoms are present, as opposed to the remission phase, innwhich signs and symptoms are absent. ${ }^{6}$

Uncontrolled UC is a socially limiting condition due to the embarrassing symptoms, causing absenteeism in school and work and frequent consultations for medical care, in addition to emotional and behavioral difficulties. ${ }^{6}$ Ulcerative colitis is a disease with a high negative impact on quality of life, and the treatment is lengthy and must be maintained even in the remission phase, thus increasing the risk of medication nonadherence. $^{7,8}$
Patients with UC make use of medications that require high adherence to avoid worsening the clinical condition. ${ }^{9}$ Non-adherence was associated with an increased risk of disease, outbreaks, and shorter relapse-free time. Both non-adherence ad the number of times the medication is taken per day are independent predictors of outbreaks of the disease. ${ }^{10}$ The treatment may include complex therapeutic regimens with ingestion of several pills with different times of administration, which can influence the degree of patient compliance. In addition, the lack of adherence to UC treatment is sometimes due to the difficulty in obtaining these drugs, since some of them have high costs. ${ }^{11}$

Non-adherence occurs in up to $45 \%$ of patients with inflammatory bowel disease (IBD), and is associated with an increase in symptoms and rates of relapse. ${ }^{12}$ Unfortunately, no consistent predictor of non-adherence has been identified, although some studies have reported "younger age, full-time employment, shorter disease duration, type of treatment, and psychological factors, such as a strong emotional response and loss of response to therapy, as possible risk factors". ${ }^{12}$ In Israel, a study ${ }^{7}$ identified the main causes of non-adherence to IBD medicines in the following order of frequency: skepticism about the efficacy or safety of the medication (20.5\%); holidays (15\%); problems with the prescription or pharmacy (13.5\%); or forgetfulness (10\%).

The reality about non-adherence rates is variable: in the United States, only $40 \%$ of outpatients with quiescent UC have adhered to mesalamine; in the United Kingdom, approximately $15 \%$ of patients have not replenished the drugs prescribed for the treatment of IBD; in Europe, according to a study of 203 IBD patients, the overall self-reported non-adherence rate was $29 \%$, with variations between France (13\%), Italy (26\%) and Germany (46\%)..$^{13}$ 
It appears that three specific IBD symptoms are significantly associated with a lack of adherence to the drug treatment. Arthralgia and rectal bleeding are the symptoms most frequently associated with non-adherence, while the difficulty in controlling defecation has the strongest association within the model. All of these factors are prevalent in active IBD, and have been associated with impaired quality of life and social engagement. Presentation with such symptoms, therefore, can alert health professionals to the possibility of non-adherence to the medications. ${ }^{12}$

The impact of non-adherence includes increased risk of IBD recurrence, increased disease activity, and increased health costs, which can result in complications, the need for more potent drugs, and surgical interventions. Behavioral changes can be expected by understanding the disabling consequences of recurrent exacerbations of the disease. ${ }^{12}$

The methods to measure adherence are direct or indirect. Measures based on direct criteria are considered to be the most reliable because they are based on objective verification (directly observed treatment), or on the plasma dosage of the drug, or its metabolite, in organic fluids, or even on a specific marker co-administered with the medication. Some examples of indirect measures of adherence are interviews, self-filled questionnaires, and diaries, which are susceptible to memory bias or the willingness of the patient to contribute. ${ }^{14,15}$ To minimize subjectivity, the information resulting from the interview or the questionnaire is marked by scales, which transform such data into measurable items. Other indirect measures that are considered more objective are tablet counts and the Medication Event Monitoring System (MEMS), the latter being a cap that fits on standard medicine bottles that electronically records the time and date whenever the bottle is open and closed. ${ }^{14}$

Given the high prevalence of non-adherence in UC patients and considering this a barrier to achieve optimal health results, studies to identify interventions that may result in changes within this scenario are expected. The present article desdribes an integrative review with interventions intended to improve medication adherence in UC patients.

\section{Methods}

The present articel is a review of the scientific literature carried out between April and June 2020 in the PubMed/MEDLINE database using the following medical subject headings ( $\mathrm{MeSH}$ ) terms: medication adherence; intervention; ulcerative colitis; and inflammatory bowel disease. We restricted the search to articles published in English and Portuguese between March 2010 and March 2020. The inclusion criteria are presented in Chart 1.

After duplicate exclusion, the articles were screened by title and then by abstract as to their relevance to the topic. The selected articles, which had their full texts available in PubMed/MEDLINE or in the CAPES journal portal, were retrieved, read, and analyzed for eligibility. The interventions performed in the studies were classified into four domains ${ }^{16}$ : educational interventions; behavioral interventions; cognitive behavioral interventions; and multicomponent interventions.
Chart 1 Inclusion criteria

\begin{tabular}{|l|l|}
\hline Category & Inclusion criteria \\
\hline Population & $\begin{array}{l}\text { Patients of all ages diagnosed with ulcer- } \\
\text { ative colitis }\end{array}$ \\
\hline Interventions & $\begin{array}{l}\text { Any intervention to improve medication } \\
\text { adherence in cases of ulcerative colitis }\end{array}$ \\
\hline Study design & $\begin{array}{l}\text { Clinical studies; clinical trials; controlled } \\
\text { clinical trials; multicenter studies; prag- } \\
\text { matic clinical trials; randomized controlled } \\
\text { trials }\end{array}$ \\
\hline $\begin{array}{l}\text { Publication } \\
\text { period }\end{array}$ & From March 2010 to March 2020 \\
\hline Languages & English and Portuguese \\
\hline Outcome & $\begin{array}{l}\text { Medication adherence as primary } \\
\text { or secondary outcome }\end{array}$ \\
\hline Availability & $\begin{array}{l}\text { Full-text availability at PubMed/MEDLINE } \\
\text { or CAPES journal portal }\end{array}$ \\
\hline
\end{tabular}

\section{Results}

\section{Selected Articles}

In the literature search, we retrieved 207 citation records, and, after duplicate exclusion, 63 citations remained. The citations were screened by title and abstract, followed by the retrieval of the full text of the studies and an assessment for eligibility. The flowchart of the study selection is presented in -Figure 1.

\section{Characterization of the Selected Articles}

The present review included 6 articles that were randomized trials published from 2010 to 2019. All papers were written in English, and most of them were from European countries, such as the United Kingdom, ${ }^{17,18}$ Denmark/Ireland, ${ }^{19}$ and Germany. $^{20}$ The other two studies were from the United States ${ }^{21}$ and South Korea. ${ }^{22}$ Chart 2 highlights elements of these publications.

Half of the trials $(3 ; 50 \%)^{17,19,21}$ used multicomponent interventions, whereas $2(33.3 \%)^{18,22}$ focused on behavioral interventions, and $1(16.7 \%)^{20}$ studied applied isolated educational interventions.

The studies analyzed used direct and/or indirect methods to measure adherence to the drug treatment in patients with UC (Chart 3). All of them used indirect methods, which can be explained due to their low cost and ease of use. One trial ${ }^{18}$ used self-reported data, another ${ }^{22}$ used diaries, while 4 (66.7\%) trials used scales/questionnaires such as the "Morisky Medication Adherence Scale" (MMAS), ${ }^{20,21}$ the "Beliefs about Medication Questionnaire" (BMQ), ${ }^{17}$ and "the compliance questionnaire". ${ }^{19}$

In total, $3(50.0 \%)$ studies $^{18,19,22}$ associated 2 or more types of indirect methods: 1 (16.7\%) of them associated a pharmacy database evaluation, ${ }^{19}$ while one of the indirect methods was the Medication Event Monitoring System (MEMS).${ }^{18}$ In 2 (33.3\%) studies, ${ }^{17,20}$ direct methods such as dosing the drug or its metabolites in organic fluids were associated with indirect methods. 


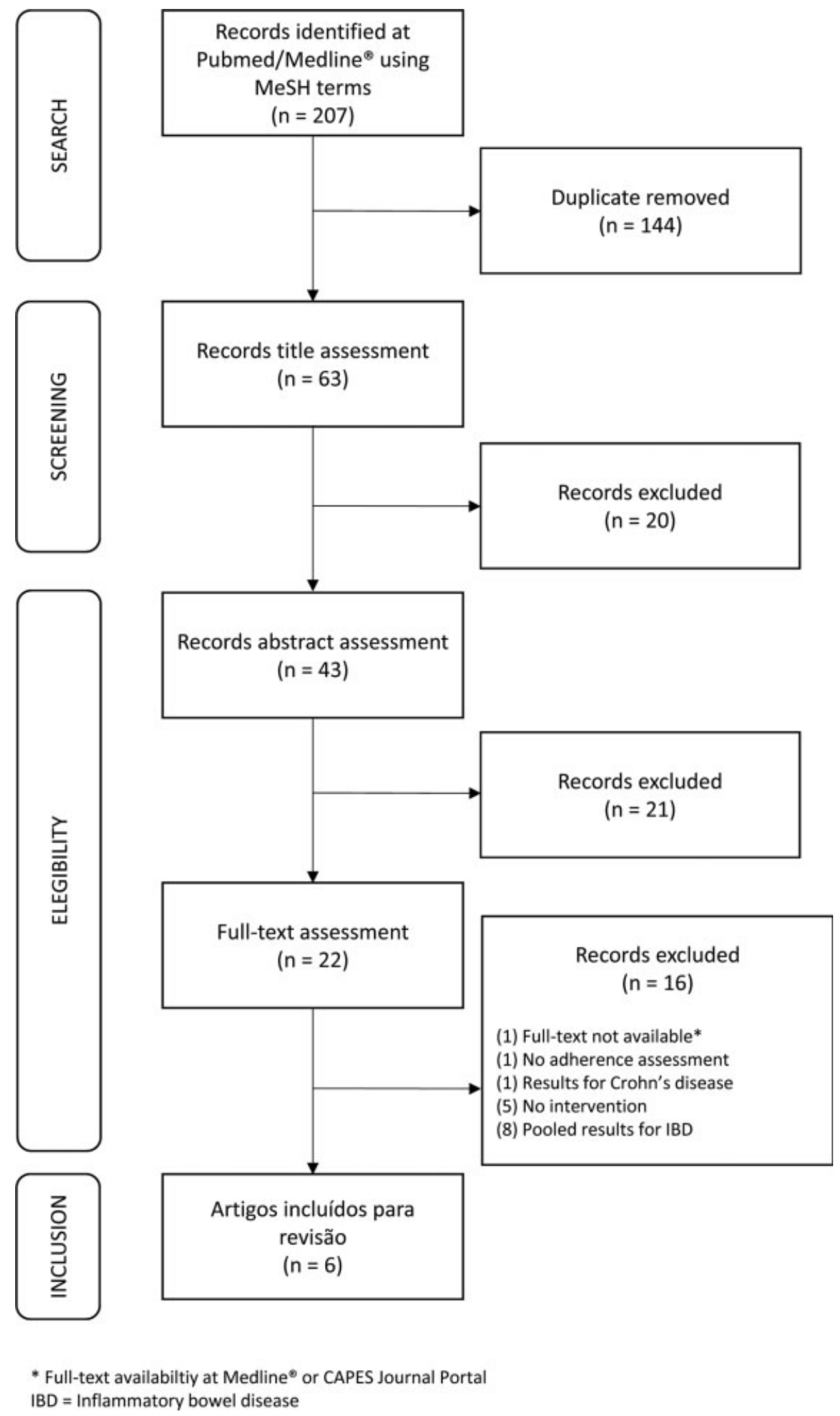

Fig. 1 Flowchart of the study selection.

\section{Characterization of Studies' Interventions}

\section{Educational Interventions}

Educational interventions aim to improve the patient's knowledge about the characteristics and symptoms of UC, as well as the benefits and side effects of the treatment, the consequences of non-adherence, among other information. ${ }^{16}$ An isolated educational intervention was used in $1(16.7 \%)$ of the selected studies, ${ }^{20}$ whichand is described below.

The study ${ }^{20}$ was a multicenter randomized controlled trial conducted in Germany to investigate the influence of a structured patient education intervention on adherence to 
Chart 2 Articles presenting interventions to improve medication adherence in UC

\begin{tabular}{|c|c|c|c|c|}
\hline $\begin{array}{l}\text { Authors, Year, } \\
\text { Country }\end{array}$ & $\begin{array}{l}\text { Study design; } \\
\text { sample size }\end{array}$ & Objectives & Type of intervention* & Adherence results \\
\hline $\begin{array}{l}\text { ELKJAER et al., }{ }^{19} 2010 \\
\text { (Denmark and Ireland) }\end{array}$ & $\begin{array}{l}\text { Randomized } \\
\text { clinical trial; } 333\end{array}$ & $\begin{array}{l}\text { To validate the influence } \\
\text { of interventions on } \\
\text { self-management, } \\
\text { adherence and quality of } \\
\text { life }\end{array}$ & $\begin{array}{l}\text { Multicomponent } \\
\text { Educational interven- } \\
\text { tions and web-based } \\
\text { treatment solution } \\
\text { program to patients and } \\
\text { caregivers vs. controls }\end{array}$ & $\begin{array}{l}\text { The differences in the } \\
\text { adherence to four weeks of } \\
\text { acute treatment were } \\
\text { statistically significant, } \\
\text { being higher in the web } \\
\text { group than in the control }\end{array}$ \\
\hline $\begin{array}{l}\text { MOSHKOVSKA et al., }{ }^{17} \\
2011 \text { (United Kingdom) }\end{array}$ & $\begin{array}{l}\text { Exploratory } \\
\text { randomized } \\
\text { controlled } \\
\text { trial; } 71\end{array}$ & $\begin{array}{l}\text { To evaluate a multiface- } \\
\text { ted adherence-enhanc- } \\
\text { ing intervention over a } \\
12 \text {-month period }\end{array}$ & $\begin{array}{l}\text { Multicomponent } \\
\text { Tailored interventions: } \\
\text { educational and cogni- } \\
\text { tive behavioral (optional } \\
\text { components: simplified } \\
\text { dosing regimens, practi- } \\
\text { cal reminders, pill } \\
\text { dispensers) versus } \\
\text { controls }\end{array}$ & $\begin{array}{l}\text { The intervention group had } \\
\text { a significant positive impact } \\
\text { on maintaining adherence } \\
\text { levels after adjusting for } \\
\text { potential confounders }\end{array}$ \\
\hline $\begin{array}{l}\text { CROSS et al., }{ }^{21} 2012 \\
\text { (United States of America) }\end{array}$ & $\begin{array}{l}\text { Randomized } \\
\text { controlled } \\
\text { trial; } 47\end{array}$ & $\begin{array}{l}\text { To evaluate the impact of } \\
\text { telemedicine for ulcera- } \\
\text { tive colitis on disease } \\
\text { activity, quality of life, } \\
\text { and adherence }\end{array}$ & $\begin{array}{l}\text { Multicomponent } \\
\text { Ulcertative colitis home } \\
\text { automated telemanage- } \\
\text { ment system (UC HAT) } \\
\text { versus best available care }\end{array}$ & $\begin{array}{l}\text { No differences in adherence } \\
\text { rates during the study }\end{array}$ \\
\hline $\begin{array}{l}\text { GILLESPIE et al., }{ }^{18} \\
2014 \text { (United Kingdom) }\end{array}$ & $\begin{array}{l}\text { Substudy of a } \\
\text { randomized } \\
\text { multicenter } \\
\text { study; } 58\end{array}$ & $\begin{array}{l}\text { To evaluate the impact of } \\
\text { one daily dose on medi- } \\
\text { cation adherence }\end{array}$ & $\begin{array}{l}\text { Behavioral } \\
2 \text { dosing regimens: } 2.4 \mathrm{~g} \\
\text { once a day versus } 3 \text { daily } \\
\text { doses of } 800 \mathrm{mg} \text { of } \\
\text { mesalamine }\end{array}$ & $\begin{array}{l}\text { Three-dose participants } \\
\text { were generally less adherent } \\
\text { than one-dose participants }\end{array}$ \\
\hline $\begin{array}{l}\text { NIKOLAUS et al., } \\
2017 \text { (Germany) }\end{array}$ & $\begin{array}{l}\text { Multicenter } \\
\text { randomized } \\
\text { controlled } \\
\text { trial; } 248\end{array}$ & $\begin{array}{l}\text { To investigate the } \\
\text { influence of a structured } \\
\text { patient education inter- } \\
\text { vention on mesalamine } \\
\text { adherence }\end{array}$ & $\begin{array}{l}\text { Educational } \\
\text { Educational program } \\
\text { versus standard care }\end{array}$ & $\begin{array}{l}\text { No differences in medica- } \\
\text { tion adherence rates during } \\
\text { the study }\end{array}$ \\
\hline $\begin{array}{l}\text { PARK et al., }{ }^{22} 2019 \\
\text { (South Korea) }\end{array}$ & $\begin{array}{l}\text { Randomized } \\
\text { control trial; } \\
180\end{array}$ & $\begin{array}{l}\text { To assess adherence to } \\
\text { different } 5 \text {-aminosalicylic } \\
\text { acid administration } \\
\text { regimes }\end{array}$ & $\begin{array}{l}\text { Behavioral } \\
2.4 \mathrm{~g} \text { of mesalamine in } \\
\text { different dosages: once a } \\
\text { day versus divided doses } \\
\text { ( } 2 \text { or } 3 \text { times a day) }\end{array}$ & $\begin{array}{l}\text { No statistically significant } \\
\text { differences were found be- } \\
\text { tween the different admin- } \\
\text { istration regimes }\end{array}$ \\
\hline
\end{tabular}

Note: *According to Greenley et al., ${ }^{16} 2013$ (educational; behavioral; cognitive behavioral; multicomponent).

Chart 3 Methods used to assess medication adherence by the included studies

\begin{tabular}{|c|c|c|}
\hline \multirow[t]{2}{*}{ ARTICLES } & \multicolumn{2}{|c|}{ ADHERENCE ASSESSMENT METHOD } \\
\hline & Direct & Indirect \\
\hline ELKJAER et al., ${ }^{19} 2010$ & - & $\begin{array}{l}\text { The compliance questionnaire; } \\
\text { pharmacy database evaluation }\end{array}$ \\
\hline MOSHKOVSKA et al., ${ }^{17} 2011$ & $\begin{array}{l}\text { Urinary concentration of 5-aminosalicylic acid } \\
\text { and N-acetyl-5-aminosalicylic acid }\end{array}$ & Beliefs about Medication Questionnaire \\
\hline CROSS et al., ${ }^{21} 2012$ & - & Morisky Medication Adherence Scale \\
\hline GILLESPIE et al., ${ }^{18} 2014$ & - & $\begin{array}{l}\text { Medication Event Monitoring System; } \\
\text { self-report; tablet counts }\end{array}$ \\
\hline NIKOLAUS et al., ${ }^{20} 2017$ & $\begin{array}{l}\text { Urinary concentration of 5-aminosalicylic acid } \\
\text { and } \mathrm{N} \text {-acetyl-5-aminosalicylic acid }\end{array}$ & Morisky Medication Adherence Scale \\
\hline PARK et al., 222019 & - & Diary; tablet counts \\
\hline
\end{tabular}

mesalamine. A total of 248 patients with inactive or mildly active UC were included. The control group was submitted to standard care, whereas the intervention group underwent standard care and an educational program. The program was delivered by a nurse or physician, and it included showing standardized slides for at least 2 hours and a group discussion with the following topics: UC etiology; disease course; complications; therapy regimen; and strategies to prevent relapses. The baseline characteristics of both groups were similar, except for the rate of anti-tumor necrosis factor $\alpha$ 
(anti-TNF $\alpha$ ) treatment in the control and intervention groups ( $10.7 \%$ versus $25 \%$ respectively). The educational measures had no influence on adherence rates between the groups $(52.5 \%$ of non-adherents in the control group, and $52.4 \%$ of non-adherents in the intervention group; $p=0.99$ ), even after adjustment for the use of anti-TNF $\alpha$. The variables associated with non-adherence in the study were younger age and recent disease diagnosis. The authors found a tendency for association between lower levels of schooling and non-adherence.

\section{Behavioral Interventions}

This domain of interventions aims to reinforce adherence by encouraging the behavior of taking the medication, or modifying environmental factors such as simplifying the drug regimen, issuing reminders, or giving rewards for complying with the prescribed medication. ${ }^{16}$ Behavioral interventions were used in 2 (33.3\%) studies included in the present review, which are described below.

One article $^{18}$ presented a sub-study of a multicenter randomized trial ${ }^{23}$ which aimed to investigate whether dosing mesalamine once a day had an influence on medication adherence in a subset of 58 UC patients. The intervention proposed were 2 dosing regimens of $2.4 \mathrm{~g}$ /day of mesalamine: 1 group would take 3 tablets containing $800 \mathrm{mg}$ once a day, while the other group would take the same dose administered 3 times throughout the day, as maintenance therapy. The patients were exposed to the interventions for twelve months. Regarding the results, no demographic factors were associated with medication adherence. The authors consistently observed a difference between the one-dose and three-dose regimens through 2 assessment methods for medication adherence (98.9\% versus.94.2\% for tablet counts $[p=0.005]$; and $96.6 \%$ versus $54.9 \%$ for the MEMS [ $p<0.001$ ] respectively), while no statistical difference was observed regarding the self-reported adherence method. The authors recognize some limitations, such as only asking whether patients had taken their tablets as prescribed at least $90 \%$ of the time and the ease of medication taking instead of a validated self-reported questionnaire. They also reported that the MEMS cap is a bulky device that may be difficult to carry throughout the day for the patients in the three-dose regimen.

Another randomized controlled trial, ${ }^{22}$ conducted in South Korea with 180 UC patients in remission, used 2 different mesalamine regimens: 1 daily tablet containing $2.4 \mathrm{~g}$ of Asacol (Medeva Pharma Suisse AG, Bulle, Switzerland); or the same dose divided (either $1.2 \mathrm{~g}$ twice a day or $800 \mathrm{mg} 3$ times a day) for 12 months. The baseline characteristics were homogeneous, except for the body mass index, which was significantly higher in the divided-dose group. Regarding the results, the study found no statistical significance between the groups regarding the rates of medication adherence for any of the methods. The authors discuss that, regarding medication adherence, the two-dose regimen might have a less dramatic result when compared to the one-dose regimen. This could have interfered in their results due to higher proportion of patients in the divided-dose group (76.5\% twice a day and $23.5 \%$ three times a day). However, the patients who received only one daily dose were more satisfied with the administration regimen than those who received two or three daily doses.

\section{Cognitive Behavioral Interventions}

This category of interventions aims to promote adherence by altering the thinking patterns that may relate to non-adherence. ${ }^{16}$ No study included in our review used isolated cognitive behavioral interventions.

\section{Multicomponent Interventions}

This group of interventions is comprised of multiple strategies, which may include educational, behavioral, cognitive behavioral, motivational, and/or support provision strategies. ${ }^{16} \mathrm{~A}$ total of 3 (50.0\%) studies included in the present review used multicomponent interventions, and they are described below.

A study in the United Kingdom ${ }^{17}$ reported to be effective in improving adherence rates among patients with UC through a personalized multiple intervention approach. The intervention program included educational components (information about the disease and treatment) and cognitive behavioral components (discussions about barriers to adherence and strategies to surpass them). The sessions lasted up to 30 minutes, and, at the end, an educational leaflet was offered to the patients. Several other optional behavioral components, such as simplification of the treatment schedule, reminders, use of pill organizers, and alarm setup were offered. This study was structured as an exploratory randomized controlled trial, and medication adherence was assessed through direct and indirect methods at baseline and after 12 months. In total, 71 patients using 5-aminosalicylic acid (5-ASA) completed the study, and although the adherence levels declined over time, the authors stated that the intervention group had a significant positive impact on maintaining adherence levels after adjusting for potential confounding factors. The authors discuss some limitations, such as the fact that less than half of the patients approached agreed to take part in the study, and the extent to which this could have influenced their outcomes is unknown. They mentioned that their sample contained a low proportion of non-adherents at baseline, and this could lead to a bias. This was an exploratory trial; therefore, they suggest future studies with larger samples.

In Denmark and Ireland, a randomized controlled clinical trial $^{19}$ was conducted with 333 patients using 5-ASA derivates to treat mild to moderate UC. This study used ConstantCare, an online platform with information about the disease and treatment, in addition to modules to record signs and symptoms. This web-guided approach aimed to deliver information and educate, while in the case of disease relapse, the program algorithm recommended a treatment for remission and, after reaching remission, the system recommended a maintenance dose. Within this platform, caregivers could assess and keep up with the treatment and clinical status of the patients, while the patients could send direct messages to their doctor when necessary. When the patients had their therapeutic goals unmet, the system would indicate the need for in-person consultations. In this study, the self-reported method used to measure adherence included questions with dichotomized 
answers regarding the use of the mesalamine treatment, and, in Denmark, the patients' additional refill information was compared using a pharmacy prescription database. Adherence was measured at 4 -week and 12-month intervals. As a result of the study, there was a statistically significant difference between the groups in both countries regarding the adherence to 4 weeks of acute treatment, and in Denmark there was an additional improvement in quality of life and knowledge about the disease. The duration of the active disease, the number of relapse events, and the number of outpatient visits were reduced, resulting in savings of $€ 189$ per patient per year. However, no significant differences regarding medication adherence were found after 12 months of intervention.

Another randomized controlled trial ${ }^{21}$ using multicomponent elements was conducted in the United States for 12 months with 47 adult patients diagnosed with UC. The participants underwent visits every four months, and their intervention was the use of a home automated telemanagement system (UC HAT), composed of a home unit, a decision support server, and a web-based clinician portal. The home unit delivered educational interventions, and the participants transmitted data weekly after self-testing sessions on their well-being, symptoms (intestinal and extraintestinal), side effects, and number of medication doses. Depending on the data inserted into the home unit, customized action plans were sent back to the participants, or alerts were sent to the nurse coordinator. At baseline, there were no differences regarding demographics, disease status, or rates of medication adherence between the groups, but there was a greater use of immune suppressants in the intervention group compared to the controls (56\% versus 27\%; $p=0.05$ ). Using the Morisky Medication Adherence Score ,the results failed to show differences in adherence rates between the groups throughout the trial, at 4, 8 and 12 months. The authors discuss that the study was powered to detect moderate differences in primary endpoints; this, added to the difference regarding the calculated sample size (84 patients) and sample obtained (47 patients), could partially explain their results. This was the only trial identified in our review that used a single method to assess medication adherence.

\section{Discussion}

Regarding the adherence assessment, all selected trials in the present review used indirect methods, which can be generally explained due to their low cost, and fast and simple use. Most studies preferred scales/questionnaires, since the process of translating self-reported information into validated scales reduces the subjectivity of the method. On the other hand, it is known that self-reported data rely on the patient's memory and willingness to contribute. ${ }^{14}$

One of the studies ${ }^{19}$ included in the present review conducted an evaluation of a pharmacy database, which is considered a strong indirect method when patients obtain their medication from a centralized pharmacy or there is a regional or national computerized system to control pharmacy refill. Although access to refill medication is important, there is no guarantee it will be taken in a rational manner. ${ }^{24}$
Some of the studies ${ }^{18,22}$ in the present review used other indirect methods that are considered more objective, such as tablet counting and the MEMS. The latter is an electronic device that records how often the bottle cap of the medication is opened. This method can establish adherence behavior over time, but it has not been routinely adopted due to its high cost. $^{24}$

The measurement of drug dosages in the urine is considered a direct method, but it is limited to some drugs that already have defined reliable and accurate analytical methods, restricting its use. ${ }^{14}$ This method was used in studies ${ }^{17,20}$ selected for the present review regarding the urinary concentration analysis of 5-ASA and metabolites. Despite providing quantifiable results, these concentrations can suffer interference due to interindividual physiological and metabolic variations. ${ }^{25}$ There are reports of a "white-coat adherence" phenomenon characterized as an improved medication adherence prior to sample collection, which could result in the overvaluation of adherence rates. ${ }^{24}$ Determination of the drug concentration in the serum or urine is an expensive method, which requires qualified labor for sample collection/analysis. This can be observed in our results, since only 2 (33.3\%) studies ${ }^{17,20}$ used urinary sample analysis.

There is a consensus that no single method is capable of capturing drug adherence in a sensitive, accurate and reliable manner. Currently, there is no gold standard, and a combination of methods to assess adherence seems the best strategy to extract the best parts of each method and reduce possible gaps, since not every method captures adherence in the same way. ${ }^{26,27}$ Our findings reflect this evidence since most trials used combined methods.

The present review resulted in only $3(50 \%)$ clinical trials ${ }^{17-19}$ that showed an effective impact on adherence rates. Two of these studies ${ }^{17,19}$ used multicomponent approaches, and all used a combination of methods to measure adherence. Combined interventions maximize the advantages of each technique, since each one focuses on different aspects of adherence. ${ }^{24}$

In the present review, regimen simplification was found to be effective to improve the adherence rate in one study ${ }^{18}$ and ineffective in another. ${ }^{22}$ A study ${ }^{16}$ not included in the review stated that dose simplification is likely most beneficial when unintentional non-adherence is related to regimen complexity. In regard to this observation, it seems that tailored interventions would favor better results, since they consider the patient's barriers to adherence and meet their individual needs.

Until the writing of this article there were no records on the Brazilian Registry Platform for Clinical Trials (REBEC, in the Portuguese acronym) of trials conducted in Brazil for this purpose, which points to a gap in the local development of knowledge in this area.

\section{Conclusions}

Due to the small number of studies that met the review's inclusion criteria, we still have little evidence of effective interventions to improve medication adherence on this subset of patients. However, there are indications that multicomponent 
interventions, when implemented properly within a trial using combined instruments to measure adherence, including validated scales/questionnaires and direct methods, are a feature of the studies that showed effectiveness. On the other hand, combined interventions should be simple enough to be implemented in routine services and benefit the largest number of patients. The possible disease complications with impact in quality of life and increased cost with parenteral treatment, including biological therapy, need to be counterbalanced in the scenario of adherence management in UC patients. We consider that future trials assessing interventions to enhance medication adherence targeting UC patients are needed.

\section{Conflict of Interests}

The authors have no conflict of interests to declare.

\section{Acknowledgments}

We appreciate the important collaboration throughout search and retrieval of articles by UNEB Pharmacy undergraduate students: Ana M G Oliveira, Daniel P C Santos, and Kilma M Domingues.

\section{References}

1 Hugtenburg JG, Timmers L, Elders PJM, Vervloet M, van Dijk L. Definitions, variants, and causes of nonadherence with medication: a challenge for tailored interventions. Patient Prefer Adherence 2013;7:675-682

2 Testa A, Castiglione F, Nardone OM, Colombo GL. Adherence in ulcerative colitis: an overview. Patient Prefer Adherence 2017; 11:297-303. Doi: 10.2147/PPA.S127039[Internet]

3 Jakovljević M Non-adherence to medication: a challenge for personcentred pharmacotherapy to resolve the problem. Psychiatr Danub 2014;26(01, Suppl 2):358-363

4 Kisa A, Sabaté E, Nuño-Solinís RADHERENCE TO LONG-TERM THERAPIES: Evidence for action. World Health Organization ${ }^{\circledR}$. Geneva2003. $211 \mathrm{p}$

5 Sairenji T, Collins KL, Evans DV. An Update on Inflammatory Bowel Disease. Prim Care 2017;44(04):673-692. Available from: https:// doi.org/10.1016/j.pop.2017.07.010

6 Feuerstein JD, Cheifetz AS. Ulcerative colitis: epidemiology, diagnosis, and management. Mayo Clin Proc 2014;89(11):1553-1563. Doi: 10.1016/j.mayocp.2014.07.002[Internet]

7 Engel T, Ungar B, Ben-Haim G, Levhar N, Eliakim R, Ben-Horin S. Re-phrasing the question: A simple tool for evaluation of adherence to therapy in patients with inflammatory bowel disease. United European Gastroenterol J 2017;5(06):880-886

8 Jackson BD, Gray K, Knowles SR, De Cruz P. EHealth technologies in inflammatory bowel disease: A systematic review. J Crohn's Colitis 2016;10(09):1103-1121

9 Trindade AJ, Morisky DE, Ehrlich AC, Tinsley A, Ullman TA. Current practice and perception of screening for medication adherence in inflammatory bowel disease. J Clin Gastroenterol 2011;45(10): 878-882

10 Ballester MP, Marti-Aguado D, Fullana M, et al. Impact and risk factors of non-adherence to 5-aminosalicylates in quiescent ulcerative colitis evaluated by an electronic management system. Int J Colorectal Dis 2019;34(06):1053-1059
11 Walsh A, Travis S. What's app? Electronic health technology in inflammatory bowel disease. Intest Res 2018;16(03):366-373

12 Perry J, Chen A, Kariyawasam V, et al. Medication non-adherence in inflammatory bowel diseases is associated with disability. Intest Res 2018;16(04):571-578

13 Lakatos PL. Prevalence, predictors, and clinical consequences of medical adherence in IBD: how to improve it? World J Gastroenterol 2009;15(34):4234-4239

14 Nguyen TMU, La Caze A, Cottrell N. What are validated self-report adherence scales really measuring?: a systematic review $\mathrm{Br} \mathrm{J}$ Clin Pharmacol 2014;77(03):427-445

15 Osterberg L, Blaschke T. Adherence to medication. N Engl J Med 2005;353(05):487-497http://www.nejm.org/doi/abs/10.1056/ NEJMra050100[Internet]

16 Greenley RN, Kunz JH, Walter J, Hommel KA. Practical strategies for enhancing adherence to treatment regimen in inflammatory bowel disease. Inflamm Bowel Dis 2013;19(07):1534-1545http://www. ncbi.nlm.nih.gov/pmc/articles/PMC3751168/[Internet]

17 Moshkovska T, Stone MA, Smith RM, Bankart J, Baker R, Mayberry JF. Impact of a tailored patient preference intervention in adherence to 5-aminosalicylic acid medication in ulcerative colitis: results from an exploratory randomized controlled trial. Inflamm Bowel Dis 2011;17(09):1874-1881https://academic.oup.com/ ibdjournal/article/17/9/1874-1881/4633789[Internet]

18 Gillespie D, Hood K, Farewell D, Stenson R, Probert C, Hawthorne $\mathrm{AB}$. Electronic monitoring of medication adherence in a 1-year clinical study of 2 dosing regimens of mesalazine for adults in remission with ulcerative colitis. Inflamm Bowel Dis 2014;20 (01):82-91

19 Elkjaer M, Shuhaibar M, Burisch J, et al. E-health empowers patients with ulcerative colitis: a randomised controlled trial of the webguided 'Constant-care' approach. Gut 2010;59(12):1652-1661

20 Nikolaus S, Schreiber S, Siegmund B, et al. Patient education in a 14-month randomised trial fails to improve adherence in ulcerative colitis: Influence of demographic and clinical parameters on non-adherence. J Crohn's Colitis 2017;11(09):1052-1062

21 Cross RK, Cheevers N, Rustgi A, Langenberg P, Finkelstein J. Randomized, controlled trial of home telemanagement in patients with ulcerative colitis (UC HAT). Inflamm Bowel Dis 2012;18(06):1018-1025https://academic.oup.com/ibdjournal/ article/18/6/1018-1025/4607754[Internet]

22 Park S-K, Park SH, Eun CS, et al. Adherence to Asacol once daily versus divided regimen for maintenance therapy in ulcerative colitis: a prospective, multicenter, randomized study. Intest Res 2019;17(03):349-356

23 Hawthorne AB, Stenson R, Gillespie D, et al. One-year investigatorblind randomized multicenter trial comparing Asacol $2.4 \mathrm{~g}$ once daily with $800 \mathrm{mg}$ three times daily for maintenance of remission in ulcerative colitis. Inflamm Bowel Dis 2012;18(10):1885-1893

24 Chan W, Chen A, Tiao D, Selinger C, Leong R. Medication adherence in inflammatory bowel disease. Intest Res 2017;15(04): 434-445www.irjournal.org[Internet]

25 Römkens TEH, Te Morsche R, Peters W, Burger DM, Hoentjen F, Drenth JPH. Urinalysis of MMX-mesalazine as a tool to monitor 5ASA adherence in daily IBD practice. Br J Clin Pharmacol 2018;84 (03):477-481

26 Lam WY, Fresco P. Medication Adherence Measures: An Overview. BioMed Res Int 2015;2015:217047

27 McRae-Clark AL, Baker NL, Sonne SC, DeVane CL, Wagner A, Norton J. Concordance of Direct and Indirect Measures of Medication Adherence in A Treatment Trial for Cannabis Dependence. J Subst Abuse Treat 2015;57:70-74 